\title{
THE VOYAGE OF DOMINGO GONZALES TO THE WORLD OF THE MOON
}

BY

\author{
DR. FRANCIS GODWIN.1
}

The Harleian Miscellany; or, a collection of scarce, and entertaining pamphlets and tracts, as well in manuscript as in print, found in the late Earl of Oxford's library, interspersed with historical, political, and critical notes. Vol. XI. London: printed

for Robert Dutton, Gracechurch-Street, p. 511-534.

A View of St. Helena, an island in the Ethiopian Ocean, in America, now in possession of the honourable EastIndian-Company, where their slips usually refresh in their Indian Voyages; With an Account of the admirable Voyage of Domingo Gonsales, the little Spaniard, to the World in the Moon, by the Help of several Gansa's or large Geese. An ingenious Fancy, written by a late learned Bishop. (Duodecimo, containing fortythree pages.)

Before I come to relate the acquisition of the English in India, \&c. I will make a halt, at St. Hellens, or Helena, which is now possessed by the honourable East-India company. It is called the Sea-Inn, because the English, and other nations stop there, as a place for watering and refreshment, in their long voyages to India. It was formerly seized by the Dutch, but retaken May to $6^{\text {th }}, 1673$, by Captain Munday, with a squadron of English ships, and three rich Dutch East-India ships made prizes in the harbour; since which the company have fortified, and secured it, against

1 Die nachstehende widergabe des Godwin'schen reiseromans gründet sich auf die Harleian Miscellanies vol. XI, p. 511-534, welche daselbst in teilweise gekürzter, in den für uns wichtigen hauptteilen jedoch genauer gestalt die reise des Domingo Gonzales zum monde berichten. Die seltenheit des Godwin'schen traktats und die wichtigkeit, dem leser sofort deutliches quellenmaterial zu liefern, dürften diesen abdruck rechtfertigen. 
any future invasion of Dutch, Portuguese, or Spaniards. It was called St. Helena, by the Portuguese, who discovered it on St. Hellen's Day, being April the second. There is no island in the world so far distant from the continent, or main land, as this. It is about sixteen leagues in compass, in the Ethiopick Sea, in sixteen degrees of south latitude; about fifteen hundred miles from the Cape of Good Hope; three-hundred and sixty from Angola, in Africa; and five-hundred and ten from Brasile, in America. It lies high out of the water, and surrounded on the sea-coasts with stecp rocks, having within many cliffs, mountains, and vallies, of which one is named Church-Valley; where behind a small church they climb up to the mountains. To the south is Apple-Dale, so called from the abundance of oranges, lemons, and pomegranates, enough to furnish five or six ships. On the west side of the church, ships have good anchorage close under the shore, to prevent the winds which blow fiercely from the adjacent high mountains.

The air seems temperate and healthful, so that sick men brought a shore there in a short time recover: yet the heat in the vallies is as intolerable as the cold upon the mountains. It commonly rains there five or six times a day, so that the barrenness of the hills is not occasioned for want of water, of which is hath two or three good springs for furnishing ships with fresh water; the ground of its own accord brings forth wild pease, and beans, also whole woods of orange, lemon, and pomegranates trees, all the year long laden both with blossoms and fruit, good figs, abundance of ebony, and rose trees, parsly, mustard seed, purslain, sorrel, and the like; the woods and mountains are full of goats, large rams, and wild swine, but difficult to be taken. When the Portuguese discovered it, they found neither four-footed beasts nor fruit trees, but ouly fresh water; they afterwards planted fruit-trees, which so increased since, that all the vallies stand full of them; partridges, pigeons, moorhens, and peacocks breed here numerously, whereof a good marksman may soon provide a dinner for his friends. On the cliff islands, on the south, are thousands of grey and black mews, or sea-pies, and white and coloured birds, some with long, others with short necks, who lay their eggs on the rocks, and suffer themselves to be taken with the hand, gazing at the surprisers, till they are knocked on the head with sticks.

From the salt water beating against the cliffs a froth, or scum, remains in some places, which the heat of the sun so purifies, that it becomes white and good salt; some of the mountains yield bole armoniack, and a fat earth like Terra Lemuia. The sea will answer the pains of a patient fisherman, who must use an angle, not a net, because of the foul ground, and beating of the waves; the chief are mackarel, roach, carp, but differing in colour from those among us; eels as big as a man's arm, and well tasted crabs, lobsters, oysters, and mussels as good as English.

It is in this island that the scene of that notable fancy, called, 'The Man in the Moon, or a Discourse of a Voyage thither, by Domingo Gonsales, is laid; written by a learned bishop', saith 
the ingenious Bishop Wilkins, who calls it a pleasant and well contrived fancy, in his ow book intitled, 'A Discourse of the New World, tending to prove that it is possible there may be another habitable World in the Moon': Wherein, among other curious arguments, he affirms, that this hath bcen the direct opinion of divers ancient, and some modern mathematiceans, and may probably be deduced from the tenents of others, neither does it contradict any principle of reason, nor faith; and that, as their world is our moon, so our world is theirs.

Now this small tract having so worthy a person to vouch for it, and many of our English historians having published, for truth, what is almost as improbable as this, as Sir Juhn Mandevil in his travels and others, and this having what they are uttcrly destitute of, that is, invention mixed with judgement; and was judged worthy to be licensed fifty years ago, and not since reprinted, whereby it would be utterly lost: I have thought fit to republish the substance thereof, wherein the author says he does not design to discourse his readers into a belief of each particular circumstance, but expects that his new discovery of a new world may find little better entertainment than Columbus had in his first discovery of America, though yet that poor espial betrayed so much knowledge as hath since increased, to vast improvements, and the then unknown is now found to be of as large extent as all the other known world; that there should be Antipodes was once thought as great a paradox as now that the moon should be habitable. But the knowledge of it may be reserved for this our discovering age, wherein our Virtuosi can by their telescopes gaze the sun into spots, and descry mountains in the moon. But this and much more must be left to the criticks, as well as the following relation of our little eye witness, and great discoverer, which you shall have in his own Spanish stile, and delivered with that grandeur, and thirst of glory, which is generally imputed to that nation.

It is known to all the countries of Andalusia, That I Domingo Gonsales was born of a noble family in the renowned city of Seville. My father's name being Therando Gonsales, near kinsman, on the mother's side, to Don Pedro Sanches, the worthy Count of Alnenera; my mother was the daughter of the famous lawyer, Otho Perez de Sallaveda, governor of Barcelona, and corrigidor of Biscay; I, being the youngest of seventeen children, was put to school, and designed to the church; but heaven proposing to use my service, in matters of far another nature, inspired me with spending some time in the wars. It was at that time, that Don Fernando, the renowned Duke d'Alva, was sent into the Law-Countries, in 1568. I, then following the current of my desire, leaving the university of Salamanca, whither my parents had sent me, without giving notice to any of my friends. got through France, to Antwerp, where I arrived in a mean condition. F or having sold my books, bedding, and other things, which yielded me about thirty ducats, and borrowed twenty more. of my father's friends, I bought a little nag, wherewith I travelled more thriftily, than usually young gentlemen do, till arriving within a league of Antwerp, some of the cursed Gueses set upon me, and bereaved me 
of my horse, money and all; so I was forced thro' necessity to enter into the service of Marshall Cossey, a French nobleman, whom I served in an honourable employ, thongh my enemies, to my disgrace, affirm, I was his horse-keeper's boy; but for that matter, I refer myself to Count Mansfield, and other persons of condition, who have often testified to many worthy men the very truth of the business, which indeed was this: Monsieur Cossey being about this time sent to the Duke d'Alva, Governor of the Low-Countries, he understanding the nobility of my birth, and my late misfortune, judging it would be no small honour to him, to have a Spaniard of that quality about him, furnished me with a horse, arms, and whatever I wanted, using my service, after I had learned French, in writing his letters, because my hand was very fair. In time of war, if upon necessity, I sometimes dressed my own horse, I ought not to be reproached therewith, since I count it the part of a gentleman, to submit to the vilest office for the service of his prince.

The first expedition I was in was, when the Marshall, my friend, met the Prince of Orange making a road into France, and forced him to fly, even to the walls of Cambray. It was my good fortune to defeat a trooper, by killing his horse with my pistol, who, falling upon his leg, could not stir, but yielded to my mercy. I knowing my own weakness of body, and seeing him a lusty toll fellow, thought it the surest way to dispatch him; which having done, I plundered him of a chain, money, and other things, to the value of two-hundred ducats. This money was no sooner in my pockets, but I resumed the remembrance of my nobility, and taking my audience of leave from Monsieur Cossey, I instantly repaired to the Duke d'Alva's court, where divers of my kindred, seeing my pocket full of good crowns, were ready enough to acknowledge me. By their means I was received into pay, and in time obtained favour with the Duke, who would sometimes jest a little more severely at my personage, than I could well bear; for though I must acknowledge my stature is so little, as I think no man living is less, yet since it is the work of heaven, and not my own, he ought not to have upbraided a gentleman therewith; and those glorious things that have happened to me may evince, that wonderful matters may be performed by very unlikely bodies, if the mind be good, and fortune second our endevours.

Though the Duke's jokes a little disgusted me, yet I endeavoured to conceal my resentment; and, accommodating inyself to some other of his humours, I was so far interested in his favour, that at his going into Spain, whither I attended him, by his kindness, and other accidents, wherein by my industry, I was seldom wanting to myself, I was able to carry home three-thousand crowns in my pocket.

At my return, my parents, who were extremely disturbed at my departure, received me with joy; whichiwas increased, because they found I had brought wherewitlr to maintain myself, without being chargeable to them, or lessening the portions of my brothers and sisters. But doubting I would spend it as lightly as I got it, they sollicited me to marry the daughter of John Figueres, a considerable merchant of Lisbon, to which I complied, and putting my marriage-money, and good part of my own, 
into the hands of my father, I lived like a gentleman many years very happily. At length a quarrel arising between me, and Pedro Delgades, a gentleman, and kinsman of mine, it grew so high, that when no mediation of friends could prevail, we two went alone with our swords into the field, where it was my chance to kill him, though a stout proper man; but what I wanted in strength I supplied in courage, and my agility countervailed for his stature. This being acted in Carmona, I fled to Lisbon, thinking to conceal myself with some friends of my father-in-law, till the business might be accommodated. At which time, a famous Spanish count, coming from the West-Indies, published triumphant declarations, of a great victory he had obtained against the English, near the Isle of Pines, whereas in reality he got nothing at all in that voyage but blows, and a considerable loss. It had been well, if vanity and lying had been his only crimes; his covetousness had like to have been my utter ruin, though since it had proved the occasion of eternising iny name, I verily believe, to all posterity, and to the unspeakable benefit of all mortals, for ever hereafter; at least, if it please heaven that I return home safe to my country, and give perfect instructions how these almost incredible and impossible acquirerements may be imparted to the world, you shall then see men flying in the air, from one place to another; you shall then be able to send messages many hundred miles in an instant, and receive answers immediately, without the help of any creature upon earth; you shall then presently impart your mind to your friend, though in the most remote and obscure place of a populous city, and a mulitude of other notable experiments. But what exceeds all, you shall then have the discovery of a new world, and abundance of rare and incredible secrets of nature, which the philosophers of former ages never so much as dreamed of. But I must be cautious in publishing these wonderful mysteries, till our statesmen bave considered how they may consist with the policy and good government of our country, and whether the fathers of the church may not judge the divulging them prejudicial to the catholick faith, which, by those wonders I have seen above any mortal man before me, I am instructed to advance, without respect to any temporal advantage whatsoever.

But to proceed: This huffing captain pretended much discontent for the death of Delgades, who was indeed some kin to him; however he was willing to be quiet, if I wonld give him a thousand ducats. I had now, besides a wife, two sons, whom I was not willing to beggar, only to satisfy the avaricious humour of this boaster, and so was necessitated to take some other course. I imbarqued in a stout carrick bound for the East-Indies, carrying the value of two-thousand ducats to trade with, leaving as much more for the support of my wife and children behind, whatever misfortune might happen to me. In the Indies I thrived exceedingly, laying out my stock in diamonds, emeralds, and pearls, which I bought at such easy rates, that my stock safely arriving in Spain, as I understood it did, must needs yield ten for one. But having doubled Cape Buona Esperanza in my way home, I fell dangerously sick, expecting nothing but death, which had undoubtedly happened, but that we 
just then discovered the blessed Isle of St. Hellens, the only paradise I believe on earth, for healthfulness of air, and fruitfulness of soil, producing all necessaries for the life of man. It is about sixteen leagues in compass, and has no firm land or continent within three-hundred leagues, nay, not so much as an island within an hundred leagues of it; so that it may seem a miracle of nature, that, out of so vast and tempestuous an ocean, such a small rock or piece of ground should arise and discover itself. On the south is a good harbour, and near it divers small hauses built by the Portuguese to accommodate strangers, with a chapel handsomely beautified with a tower, and bell therein. Near it is a stream of excellent fresh water, divers handsome walks planted on both sides with orange, lemon, pomegranate, almond-trees, and the like, which bear fruit all the year, as do also divers others. There is store of gardenherbs, with wheat, pease, barley, and most kinds of pulse; but it chiefly aboundeth with cattle and fowl, as goats, swine, sheep, partridges, wild hens, pleasants, pigeons, and wild fowl beyond credit. But especially about February and March are to be seen large flocks of a kind of wild swans, whereof I shall have occassion to speak more hereafter, who, like our cuckows and nightingales, go away at a certain season, and are no more seen that year.

On this happy island did they set me a-shore, with a negro to attend me, where 1 recovered my health, and continued a whole year, solacing myself, for want of human society, with birds and brute beasts. Diego, my blackmoor, was forced to live in a cave at the west end of the isle, for, had we dwelt together, victuals would not have been so plenty with us; but now, if one succeeded well in hunting or fowling, the other would find means to treat him, and if both missed, we were fain to look out sharply. But this seldom happened, since no creature there fears a man more than a goat or cow, whereby I easily tamed divers kinds of birds and beasts by only muzzling then, so that till they came either to me, or Diego, they could not feed. At first I was much delighted in a kind of partridges, and a tame fox, whereof I made good use; for, if I had occasion to confer with Diego, I would take one of them muzzled and hungry, and, tying a note about his neck, beat him from me, whereupon he would straight away to Diego's cave, and, if he were not there, would beat about till he found him. Yet, this conveyance being not without some inconvenience, I persuaded Diego, who, though a fellow of good parts, was content to be ruled by me, to remove to a cape on the north-west part of the island, being, though a league off, yet within sight of my house and chapel; and so, when the weather was fair, we could, by signals, declare our minds each to other in an instant, either by night or by day, wherein we took much pleasure. If in the night I would signify anything to him, I set up a light in the bell-tower, which was a pretty large room, with a fair window well glazed, and the walls within plaistered white, so that, though the light were but small, it made a great show. After this light had stood half an hour, I covered it, and then, if I saw any signal of light again from my companion, I knew he waited for my notice; and so, by hiding and shewing my light, according 
to the agreement betwixt us, I certified him of what I pleased. In the day, I advised him by smoke, dust and other refined ways.

After a while I grew weary of it as too painful, and again used my winged messengers. Upon the shore, about the mouth of our river, I found store of a kind of wild swans feeding upon prey, both of fish and birds; and which is more strange, having one claw like an eagle, and the other like a swan. These birds breeding here in infinite numbers, I took thirty or forty of them young, and bred them up by hand for recreation; yet, not without some thoughts of that experiment which I after put in practise. These being strong, and able to continue a great flight, I taught them, first to come at call afar off, not using any noise, but only shewing them a white cloth; and here I found it true what Plutarch affirms. That creatures which eat flesh are more ducible than others. It is wonderful to think what tricks I taught them before they were a quarter old; amongst others, I used them, by degrees, to fly with burdens, wherein I found them able beyond belief, and a white sheet being displayed to them, by Diego, upon the side of a hill, they would carry from me, to him, bread, flesh, or whatever I pleased, and, upon the like call, come to me again. Having proceeded thus far, I consulted how to join a number of them together, so as to carry a heavier weight, which, if I could compass, I might enable a man to be carried safely in the air from one place to another. I puzzled my wits extremely with this thought, and, upon trial, found, that, if many were put to the bearing of one great burden, by reason it was impossible all of them should rise together just at one instant, the first that rose, finding. himself stayed by a weight heavier than he could stir, would soon give over, and so the second, third, and all the rest. I contrived, at lust, a way, whereby each might rise with only his own proportion of weight. I fastened about each gansa a little pulley of cork, and, putting a string of a just length through it, I fastened one end to a block of almost eight pounds weight, and tied a two-pound weight to the other end of the string, and then, causing the signal to be erected, they all rose together, being four in number, and carried away my block to the place appointed. This hitting so luckily, I added two or three birds more, and made trial of their carrying a lamb, whose happiness I much envied, that he should bo the first living creature to partake of such an excellent device.

At length, after divers of trials, I was surprised with a great longing to cause myself to be carried in the same manner. Diego, my Moor, was likewise possessed with the desire, and, had I not loved him well, and wanted his service, I should have resented his ambitious thought; for I count it a greater honour to have been the first flying man, than to be another Neptune, who first adventured to sail on the sea. Yet, seeming not to understand his intention, I only told him, that all my gansa's were not strong enough to carry him, being a man, though of no great bulk, yet twice heavier than myself. Having prepared all necessaries, I, one time, placed myself and all my utensils, on the top of a rock at the river's mouth, and putting myself upon my engine at full sea, I caused 
Diego to advance the signal: whereupon my birds, twenty-five in number, rose all at once, and carried me lustily over to the rock on the other side, being about a quarter of a league. I chose this time and place, because, if any thing had fallen out contrary to expectation, the worst that could happen was only falling into the water, and being able to swim well, I hoped to receive little hurt in my fall. When I was once safe over, 0 how did my heart even swell with joy and admiration at my own invention! How often did I wish myself in the midst of Spain, that I might fill the world with the fame of my glory and renown? Every hour I had a longing desire for the coming of the Indian fleet, to take me home with them, which then staid three months beyond their usual time. At length they arrived, being three carricks, much weather-beaten, the men sick and weak, and so were constrained to refresh themselves in our island a whole month. The admiral was called Alphonso de Xima, a valiant wise man, desirous of glory, and worthy better fortune than afterwards befell him. To him I discovered my device of the gansa's, being satisfied that it was impossible, otherwise, to persuade him to take so many birds into this ship, who, for the niceness of their provisions, would be able troublesome than so many men. Yet I adjured him, by oaths and imprecations, to be secret in the business, though I did not much doubt it, assuring myself he durst not impart the experiment to any, before our king was acquainted therewith. I had more apprehension, lest ambition, and the desire of gaining to himself the honour of so admirable an invention, should tempt him to dispatch me. However, I was forced to run the risque, unless I would adventure the loss of my birds, the like whereof, for my purpose, were not to be had in Christendom, nor was I sure ever to bring up others to serve my turn.

It happened all these doubts were causeless; the man I believe was honest, but the misfortune we met with prevented all these thoughts. 'Thursday, June the 21st, 1599, we set sail for Spain, I having allowed me a convenient cabbin for my birds, and engine, which the captain would have persuaded me to have left behind, and it was a wonder I did not; but my good fortune saved my life, for, after two months sail, we met with an English fleet about ten leagues from the island of Teneriffe, one of the Canaries, famons for a hill therein called Pike, which is discerned at sea above an hunderd leagues off. We had a-board five times their number of men, all in health, and were well provided with ammunition; yet, finding them resolved to fight, and knowing what infinite riches we carried, concluded it better, if possible, to escape than, by encountering a crew of deparate fellows, to hazard not only our own lives, which a man of courrage does not value, but the estates of many poor merchants, who, I am afraid, were undone by the miscarriage of this business. Our fleet consisted of five sail, that is, three carricks, a barque, and a caravel, who, coming from St. Thomas's isle, had, in an ill hour, overtaken us some days before. The English had three ships well provided, who, no sooner espied, but presently ingaged us, and changing their course, endeavoured to bring us under their lee; which they might easily do as the wind then stood, they being light nimble vessels, as 
English ships generally are: ours heavy, deep-laden, and foul with the sea. So our captain resolved, wisely enough it may be, but neither valiantly nor fortunately, to fly, commanding us to disperse ourselves. The caravel, by too much baste, fell upon one of the carricks, and bruised her so, that one of the English easily fetched her up and entered her, the caravel sinking before our eyes. The barque escaped unpursued, and another of our carricks, after some chace, was given over by the enemy, who, expleting a sufficient body of us, and getting us between them, fell upon us with much fury. Our captain, hereupon, gave direction to run a-shore upon Teneriffe, the port whereof we could not recover, saying. That he hoped to save part of the goods, and some of our lives, and he had rather the rest should be lost, than all fall into the mercy of our foes.

When I heard this resolution, observing the sea to work high, and knowing all the coast to be so full of rocks and shoals, that it was impossible our ship should come near the land, unless broken into a thousand pieces, I represented to the captain the desperateness of the attempt, wishing him rather to try the kindness of the enemy, than throw away himself and so many brave man. But he would by no remonstrances be removed from his resolution; therefore, finding it high time to shift for myself, I locked up my little casket of jewels, which putting into my sleeve, I then betook me to my gansa's; - and, having harnessed them to my engine, and put myself thereon, supposing, as indeed it happened, that, when the ship should split, my birds, though they wanted their signal, yet, for saving their own lives (which nature has taught all creatures to preserve) would make toward land; which fell out according to my expectation. The people in the ship wondered what I was doing, none being acquainted with the use of my birds, but the captain, Diego being in the other ship, whit fled away unpursued. We were about half a league from land, when our carrick struck upon a rock, and split to pieces; upon which I let loose the reins to my. birds, having first placed myself upon the top of the deck, and with the shock they all arose, carrying me fortunately to the land; of which you need not doubt but I was very joyful, though it was a miserable sight to behold my friends and acquaintance in that woeful distress; of whom yet many escaped better than they expected. For the English, launching out their cockboats, discovered more generous tempers than we are pleased to allow them, taking compassion of their calamity, and endeavouring with all diligence to save them from the fury of the waves, though with much danger to themselves. Among others they took up our captain, who, as Father Pacio since told me, having put himself with twelve others into the cock-boat, was forced to yield to one Capt. Raymundo, who carried him and our pilot along with them in their voyage to the East-Indies, whither they were bound; but it was their hard fate, by a breach of the sea near Cape Buona Esperanca, to be swallowed by the merciless waves, whose rage they a while before had so hardly escaped. The rest as I likewise heard, who were about twenty-six persons, they took into their ship, and set them on land at Cape Verde. 
As for myself, being now a-shore in an island inhabited by Spaniards, I reckoned I was safe, but found myself mistaken; for it was my hap to pitch upon that part of the isle where the Pike begins to rise, which is inhabited by a savage people, who live upon the sides of that hill, the top whereof is for the most part covered with snow, and formerly accounted, for its steepness, inaccessible either for man or beast. But these sovages, fearing the Spaniards, keep as near the top as they can, never coming into the fruitful vallies, but to seek for booty. A crew of these out-laws happened to espy me soon after. I landed, and, thinking they had got a prize, approached me with all speed. I guessed their design before they came within half a mile, when, perceiving them come down the hill directly towards me, with long staves and other weapons, I thought it necessary to secure myself from these vilains, who, out of hatred to us Spaniards, would have cut me to pieces. The country was sandy, but the Pike beginning to lift up itself, I espied in the side a white cliff, which I hoped my gansa's would take for a mark, and, being put up, would make all that way; whereby I might be carried so far, that those barbarous rascals should not overtake me, before I got to some Spaniards house, or hide myself, till by the covert of the night I might travel to Laguna, the chief city of the island, three miles off. So I settled myself upon my engine, and let loose the reins to my gansa's, who by good fortune took all one course, though not just the way I aimed at. But what of that? 0 reader, prick up thy ears, and prepare thyself to hear the strangest chance that ever happened to any mortal, and which I know thou wilt not have the grace to believe, till thou seest the like experiment, which I doubt not in a short time may be performed. My gansa's like so many horses that had gotten the bit between their tecth, made not their flight towards the cliff I intented, though I used my wonted means to direct the leader of the flock that way, but with might and main took up toward the top of the Pike, and never stopped till they came there; a place, in vulgar estiunation (though since experimentally contradicted) fifteen miles in height. What kind of place this was I would gladly relate, but that I hasten to matters of greater importance. When I was set down there, my poor gansa's fell to panting, blowing, and gaping for breath, as if they would all bave died; so I did not trouble them a while, forbearing to draw them in (which they never use to endure without struggling) but little did I expect what followed.

It was now the season that these birds take their flight away, as our cuckows and swallows do in Spain towards autumn; and as I afterwards found, being mindful of their usual voyage, just when I began to settle myself to take them in, they with one consent rose up, and, having no other higher place to make towards, to my unspekable fear and amazement, struck bolt upright, and never left lowering upward still higher and higher, for the space, as I guessed, of an hour; after which, I thought, they laboured less than before, till at length (ah wonderful!) they remained immoveable, as steadily as if they had sat upon so many perches. The lines slacked; neither I nor the engine moved at all, but con- 
tinued still,' as having no manner of weight I found then by experience what no philosopher ever dreamed of, namely, that those things, we call heary, do not fall towards the centre of the earth as their natural place, but are drawn by a secret property of the globe of the earth, or rather something within it, as the load-stone draweth iron which is within the compass of its attractive beams; for, though my gansa's could continue unmoved, without being sustained by any thing but the air, as easily and quietly as a fish in the water, yet, if they forced themselves never so little, it is impossible to imagine with what swiftness they were carried, either onward, downward, or sideways. I must ingenuously confess, my horror and amazement in this place was such, that, had I not been armed with a true Spanish resolution, I should certainly have died for fear.

The next thing that disturbed me was the swiftness of the motion, which was so extraordinary, that it almost stopped my breath; if I should liken it to an arrow out of a bow, or a stone thrown from the top of an high tower, it would come vastly short of it. Another thing was exceeding troublesome to me, that is, the illusion of devils and wicked spirits, who, the first day of my arrival, came about me in great numbers, in the likeness of men and women, wondering at me like so many birds about an owl, and speaking several languages which I understood not, till at last I met with some that spoke good Spanish, some Dutch, and others Italian; all which I understood; and here I had only a touch of the sun's absence once for a short time, having him ever after in my sight. Now, tho' my gansa's were entangled in my lines, yet they easily seized upon divers kinds of flies and birds, especially swallows and cuckows, whereof there were multitudes, even like motes in the sun, though I never saw them eat any thing at all. I was much obliged to those (whether men or devils, I know not), who, among divers discourses, told me, 'If I would follow their directions, I should not only be carried safe home, but be assured to command at all times all the pleasures of that place'. To which motion not daring to give a flat denial I desired time to consider, and withal intreated them (though I felt no hunger at all, which may seem strange) to help me to some victuals, lest I should starve in my journey; so they readily brought me very good flesh and fish of several sorts, and well dressed, but that it was extreme fresh, without any relish of salt. Wine likewise I tasted of divers kinds, as good as any in Spain, and beer, no better in all Antwerp. They advised me, that, while I had opportunity, I should make my provisions, telling me, that till the next Thursday they could help me to no more; at which time they would find means to carry me back, aud set me safe in Spain, in any place I would desire, provided I would become one of their fraternity, and enter into such covenants as they had made to their captain and master, whom they would not name. I answered civilly, I saw little reason to rejoice in such an offer, desiring them to be mindful of me as occasion served. So for that time I was rid of them, having first furnished my pockets with as much victuals as 
I could thrust in, among which I would be sure to find a place for a small bottle of good Canary.

I shall now declare the quality of the place wherein I was; the clonds I perceived to be all under between me and the earth. The stars, because it was always day, I saw at all times alike, not shining bright as we see in the night upon earth, but of a whitish colour, like the moon with us, in the day time. 'Those that were seen, which were not many, shewed far greater than with us, yea as I guessed no less than ten times bigger; as for the moon, being then within two days of the change, she appeared of an huge and dreadful greatness. It is not to be forgot, that no stars appeared, but on that part of the hemisphere next the moon, and the nearer to her, the larger they appeared again; whether I lay quiet, and rested, or were carried in the air, I perceived myself to be always between the moon and the earth, whereby it is plain that my gansa's took their way directly towards the moon, and that when we rested, as we did at first for many hours, either we were insensibly carried round about the globe of the earth, though I perceived no such mution, or else, according to the opinion of Copernicus, the earth is carried about, and turneth round perpetually from west to east, leaving to the planets only that motion, which the astronomers call natural, and is not upon the poles of the equinoctial, commonly called the poles of the world, but upon those of the zodiack. The air in that place I found without any wind, and exceeding temperate, neither hot nor cold, where neither the sunbeams had any subject to reflet upon, nor the earth and water so near to affect the air with their natural quality of coldness. As for the philosophers attributing heat and moisture to the air, I always esteemed it a fancy. Lastly, I remember, that, after my departure from the earth, I never felt either hunger, or thirst, whether the purity of the air, freed from the vapours of the earth and water, might yicld nature sufficient nourishment, or what else might be the cause, I cannot determine, but so I found it, though I was perfectly in health, both of body, and mind, even above my usual vigour.

Some hours after the departure of that develish company, my gansa's began to bestir themselves, still directing their course towards the globe, or body of the moon, making their way with such incredible swiftness, that I conceive they advanced little less than fifty leagues in an hour, in which passage I observed three things very remarkable; one, that the farther we went, the less the globe of the earth appeared to us, and that of the moon still larger. Again the earth, which I had ever in my eye, seemed to mask itself with a kind of brightness like another moon, and as we discerncertain spots, or clouds as it were in the moon, so did I then see the like in the earth; but wharcas the form of those spots in the moon is always the same, these on the earth seemed by degrees to change every hour; the reason whereof seems to be, that whereas the earth, according to her natural motion (for such a motion I am now satisficd she hath according to the opinion of Coper- 
nicus), turns round upon her own axis, every four and twenty hours, from west to east, I should at first see in the middle of the body of this new star, the earth, a spot like a pear with a morsel bit out on one side, in some hours I should observe this spot move away towards the east, this no doubt was the main land of Africa; then might I perceive a great shining brightness in that place which continued about the same time, and was questionless the vast Atlantik 0cean. After this succeeded a spot almost oval, just as we see Americadescribed in our maps; then anotherimmense clearness representing Mare del Zur, or the South Sea; and lastly a number of spots like the countries and islands in the East Indies, so that it seemed to me no other than an huge mathematical globe turned round leisurely before me, wherein successively all the countries of our earthly world were within twenty-four hours represented to my view; and this was all the means I now had to number the days, and reckon the time.

I could now wish that philosophers and mathematicians would confess their own blindness, who have hitherto made the world believe that the earth hath no motion, and to confirm it are forced to attribute to very one of the celestial bodies two motions directly contrary to each other; one from the east to the west, to be performed in twenty-four hours, with an impetuous rapid motion; the other from west to east in several proportions. 0 incredible supposition! That those huge bodies of the fixed stars in the highest orb, whereof they confess divers are above an hundred times bigger than the whole earth, should like so many nails in a cart-wheel be whirled about in to short a time; whereas it is many thousand years, no less (say they) than thirty-thousand, before that orb finishes his course from west to east, which they call his natural motion. Now whereas they allow their natural course, from west to east, to every one of them therein, they do well; the moon performs it in twenty-seven days, the Sun, Venus, and Mercury, in a year, or thereabouts; Mars in three years, Jupiter in twelve, and Saturn in thirty. But to attribute to these celestial bodies contrary motions, at once, is an absurd conceit, and much more to imagine that the same orb, wherein the fixed stars are, whose natural course takes up so many thousands of years, should be turned about every twenty-four hours. I will not go so far as Copernicus, who makes the sun the center of the earth, and immoveable, neither will I be positive in any thing, only this I say, allow the earth its motion, which these eyes of mine can testify to be true, and all those absurdities are removed, every one having his ow $n$ single and proper motion.

But where am I? I promised an history, and am unawares turned disputer. One accident more befel me worth mention, that during my stay, I say, I saw a kind of a reddish cloud coming toward, and continually approaching nearer, which at last I perceived was nothing but a huge swarm of locusts. He that reads the discourses of learned men concerning them (as John Leo, of Africa, and others, who relate that they 
are seen in the air several days before they fall on the earth) and adds thereto this experience of mine, will easily conclude that they can come from no other place, than the globe of the moon. But now give me leave to go on quietly in my journey for eleven or twelve days, during all which time I was carried directly toward the globe, or body of the moon, with such a violent whirling as is inexpressible, for 1 cannot imagine a bullet out of a cannon could make way through the vaporous and muddy air near the earth with half that celerity; which is the more strange, since wy gansa's moved their wings but now and then, and sometimes for a quarter of an hour, not at all, only holding them stretched out, as we see kites and eagles sometimes do for a short space; during which pauses, I suppose they took their naps, and times of sleeping, for other times I could perceive they never had any; for myself, I was so fastened to my engine that I durst slumber enough to serve my turn, which $I$ took with as great ease as if I had lain on the best down bed in Spain.

After eleven days passage, in this violent flight, I perceived we began to approach to another earth (if I may so call it) being the globe or very body of that star, which we call the moon. 'The first difference I found, between this and our earth, was, that it appeared in its natural colours, as soon as ever I was free from the attraction of the earth; whereas, with us, a thing, a league or two from us, puts on that deadly colour of blue. I then perceived also, that this world was the greatest part covered with a huge mighty sea, those parts only being dry land, which are to us somewhat darker than the rest of her body, I mean, what the people call, The Man in the Moon; and that part, which shines so bright, is another ocean, besprinkled with islands, which, for their suallness, wo cannot discern so far off; so that the splendor, which appears to us in the night, is nothing but the reflexion of the sun-beams, returned to us out of the water as from a looking-glass. How much this disagrees with what our philosophers teach in the schools is evident; but alas! how many of their errors hath time and experience refuted, in this our age? And among other vain conjectures, who hath not hitherto believed the upper region of the air to be very hot, as being next forsooth, to the natural place of the element of fire? More vanities, fancies, and dreans. For, after I was once free from the attractive beans of that tyrannous loadstone, the earth, I found the air altogether serene, without winds, rain, mists, or clouds, neither hot nor cold, but constantly pleasant, calm, and comfortable, till my arrival in that new world of the moon. As for that region of fire, our philosophers talk of, I heard no news of it, my eyes have sufficiently informed me, there is no such thing.

The earth had now, by turning about, shewed me all her parts twelve times, when I finished my course; for when, by my reckoning, it seemed to be (as indeed it was) Tuesday, September the eleventh; at which time the moon, being two days old, was in the twentieth degree of Libra; my gansa's seemed, by one consent, to stay their course, and rested for certain hours, after which they took their flight, and in less than an hour set me on the top of an high hill in that other world, 
where many wonderful things were presented to my sight. For I observed first, that though the globe of the earth appeared much greater there than the moon doth to us, even three times bigger, yet all things there were ten, twenty, yea thirty times larger than ours; their trees were thrice as high and above five times broader and thicker; so were their herbs, birds, and beasts, though I cannot well compare them to ours, because I found not any kind of beast or bird there, which any way resembled ours, except swallows, nightingales, cuckows, woodcocks, batts, and some kind of wild fowl; and likewise, such birds as my gansa's, all which, as I now perceived, spend their time, in their absence from us, in that world; neither do they differ in any thing from ours, but are the very same kind.

No sooner was I upon the ground, but I found myself extremely hungry. Stepping, then, to the next tree, I fastened my engine and gansa's thereto, and in great haste fell to examining my pockets, for the victuals I had reserved there; but, to my great surprise and vexation, instead of partridges and capons, which I thought I had hoarded there, I found nothing but a medley of dry leaves, goats hair, sheep or goats dung, moss, and the like; my canary wine was turned, and stunk like horse-piss. Oh the villainy and cheats of these cursed spirits, whose assistance if I had depended on, in what a condition had I been! While I stood musing at this strange metamorphosis, on o sudden, I heard my gansa's fluttering behind we, and looking back, I espied them falling greedily upon a strub, within the reach of their lines, whose leaves they fed earnestly upon, whereas, before, I had never seen them eat any green thing whatsoever; so stepping to the shrub, I put a leaf to my mouth; the laste was so excellent, that I cannot express it, and, if I had not with discretion moderated my appetite, I should have surfeited thereon; yet it happened to be a good bait for both me, and my birds, when we had most need of refreshment.

Scarce had we ended our banquet, when I saw myself surrounded with a strange kind of people, both in feature, manners, and apparel; their stature was very different, but they were generally twice as high as ours; their shape and countenance pleasant, and their habit hardly to be described; for I never saw either cloth, silk, nor other stuff, like that whereof their cloaths were made; neither can I possibly relate their colour, they being in a manner all cloathed alike. It was neither black, white, yellow, red, nor blue, nor any colour composed of these; if you ask what was it then, I must tell you, it was a colour never seen in our earthly world, and so neither to be described nor conceived by us; for, as it is hard to make a man, born blind, understand the difference between green and blue, so neither can I deceipher this moon colour, as having no affinity with any I ever beheld. I can only say, it was the most glorious and delightful that can be imagined, neither was any thing more pleasant to me, during my stay there.

Being surprised at the appearance of these people, so suddenly, and in such accoutrements, I crossed myself, and cried out, Jesu Maria; no 
sooner was the word Jesu pronounced, but young and old fell on their knees (where at I not a little rejoiced) holding up their hands on high, and repeating certain words, which I understood not; and, presently rising, again, one much taller than the rest came and kindly embraced me, and ordering, as I perceived, some of the rest to attend my birds, he took me by the hand, and led me to his dwelling, down toward the font of the hill, which was a building so great and beautiful, as nothing in our world is comparable thereto; yet afterwards I saw such as this seemed but a cottage, in respect of them. There was no door about the house less than thirty feet high, and twelve broad; the rooms were forty or fifty feet in height, and answerable in proportion; neither could they be much less, the master thereof being full twenty-eight high, and I suppose his bolly would weigh twenty-five or thirty of ours. After I had rested with him abont one of our days, he led me five leagues off to the palace of the prince of the country, the statelines whereof I have not now leisure to describe. This prince was much taller than the former, and called (as near as I ean, by letters declare it, for their sounds are not perfectly to be expressed by our characters), Pylonas, which, in their language, is first or chief, if it doth not rather denote his authority and dignity, as being the principal man in all those parts; though yet there is one supreme monarch amongst them, much greater of stature than he, commanding over all that whole world, having under him twenty-nine other princes of great power; and every one of these has twenty-four inferior governors, whereof this Pylonas was onc. The first ancestor of this great monarch came out of the earth, as they relate, and by marrying the heiress of that vast monarchy, obtaining the government, left it to his posterity, who have enjoyed it ever since, even forty-thousand moons, which is three-thousand and seventy-seven years. His name was Irdonozur, whose heirs to this day assume the same name; he, they say, having continued thereabout four-hundred moons, and begot divers children, returned (though by what means, they know not) to the earth again. I doubt, they have their fables as well as we, since our historians never mention any earthly man to have been in that world, before myself, and much less to have returned again. I cannot therefore but condemn this tradition, as false and romantick, though $I$ found learning was in great esteem among them, and they seem todetest lying and falshood, which is there severely punished, and which may yield some credit to their historical narrations; many of them live wonderfully long, even beyond belief, affirming to me, that some survived thirty-thousand moons, which is above a thousand years, so that the ages of three or four men might easily reach to the time of the first Irdonozur; and this is generally noted, that, the taller people are of stature, the more excellent are their endowments of mind, and the longer time they live; for their stature is very different, great numbers not much exceeding ours, who seldom live above a thousand moons, which is fourscore of our years; these they account base, unworthy creatures, but one degree above brute beasts, and employ in mean and servile offices, cahing them bastards, 
counterfeits, or changelings. Those, whom they account true natural lunars, or moon-men, exceed ours generally thirty times, both in quantity of body, and length of life, proportionable to the quality of the day in both worlds, theirs containing almost thirty of our days.

'I'he manner of our travel to the palace of Pylonas was more strange and incredible than any thing we have related; for, at our first setting forth, there were delivered to each of us two feather fans, like those our ladies in Spain cool themselves with in summer. You must understand, that the globe of the moon has likewise an attractive power, yet, so much weaker than the earth, that if a man do but spring upward with all his strength, as dancers do, in shewing their tricks, he will be able to mount fifty or sixty feet high; and, being then above all attraction from the moon's earth, he falls down no more, but by the help of these fans, as with wings, they convey themselvas in the air, in a short space, (though not quite so swift as birds) whither they please. In two hours time, as I could guess, by the help of these fans, we were carried through the air those five leagues, in all about sixty persons. Being arrived at the palace of Pylonas, after our conductor had declared what manner of present he had brought, I was called into him by his attendants. By the stateliness of his palace, and the reverence done him, I soon perceived his greatness and managed my affairs, in order to procure his favour, accordingly; and having, as you may remember, a certain little box or casket of jewels, the remainder of those I brought from the East-Indies, before I was introduced, I secretly took them out of my pocket, and chusing some of each sort, I made them ready to be presented, as I should think convenient.

I found him sitting in a magnificent chair of state, with his wife or queen on one hand, and his eldest son on the other, one attended by a troop of ladies, and the other of young men; and, all along the side of the room, stood a great number of handsome personages, whereof, scarce one was lower of stature than Pylonas, whose age, they report, is now one and twenty thousand moons. At my entrance, I fell on my knees, and taking out my jewels, I presented to the king seven stones of several sorts, a diamond, a ruby, an emerald, a sapphire, a topaz, and an ophal, which he accepted with joy and admiration. Then I offered the queen and prince some others, and designed to have bestowed divers more upon his attendants; but Pylonas forbid them to accept any, supposing, as I heard, they were all $I$ had, which he would have me reserve for Irdonozur, his sovereign. He then embraced me with much indearedness, and inquired divers things by signs, which I answered in the same manner, to the best of my skill; which not contenting him, he delivered me to the guard of a hundred of his giants, as I may well call them, strictly charging them, that I should want nothing fit for me; that they should suffer none of the dwarf-lunars, or little moon-men, to come near me. That I should be instructed in their language; and lastly, that they should, by no means, impart to me the knowledge of several things, by him specified; what they were I conld never understand. It may be, you long to know what Pylonas inquired of me; why, what should it be 
but, whence I came, how I arrived there, what was my name and business, with the like? To all which I answered, as near the truth as possible.

Being dismissed, I was provided with all necessaries as my heart could wish, so that I seemed to be in a paradise, the pleasures whereof did not yet so transport me, but I was much concerned with the thoughts of my wife and children, and still retaining some hope that I might again return to them. I tended my gansa's daily with much care, which yet had signified little, if other men had not done more than I could; for now the time came, when, of necessity all people of our stature, and myself likewise, must needs sleep thirteen or forteen whole days together; for, by a secret and irresistible decree of nature, when the day begins to appear, and the moon to be enlightened by the sun-beams, which is in the first quarter of the moon, all the people of our stature, inhabiting those parts, fall into a dead sleep, and are not possible to be wakened till the sun set, and is withdrawn; for as owls and bats with us cannot endure the light, so, at the first approach of the day, we begin to be amazed therewith, and fall into a slumber, which grows by degrees into a dead sleep, till the light be gone, which is in fourteen or fiveteen days, that is till the last quarter. During the sun's absence there is a twofold light, one of the sun, which I could not endure to behold, and another of the earth. Now that of the earth was at the height, for, when the noon is at the change, then is the earth a full moon to them; and as the moon increases with us, so the light of the earth decreaseth with them. I found the light, though the sun was absent, equal to that with us in the day when the sun is clouded; but toward the quarter it daily diminisheth, yet leaving still a competent light, which seems very strange; though not so remarkable as what they there report, that in the other hemisphere of the moon, contrary to that I fell upon, where during half the moon they see not the sun, and the earth never appears to them, they have yet a kind of light not unlike our moon-light, which it seems the nearness of the stars and other planets, that are at a far less distance than from us, affords them.

You must understand, that of the true lunars, or moon-men, there are three kinds, some a little tallor than we, as perhaps ten or twelve feet high; these can endure the day of the moon, when the earth shines but little, but not the beams of both, and so must then be laid asleep. Others are twenty feet high or above, who can suffer all the light both of the earth and sun. There is in a certain island (the mysteries whereof are carefully concealed) men whose stature is at least twenty-seven feet ligh. If any other come a-land there in the moon's day-time, they instantly fall asleep. This is called insula Martini, and hath a particular governor, who, as they report, is sixty-five-thousand moons old, which makes five-thousand of our years; his name is said to be Hiruch, and he, in a manner, commands Irdonozur himself, especially in that island, out of which he never removes. There is another comes often thither, who, they say, is not above half his age, that is, about thirty-three thunsand moons, or two-thousand six-hundred of our years, and he orders 
all things through the globe of the moon, in matters of religion as absolutely as the Pope doth in any part of Italy. I would fain have seen this man, but was not permitted to come near him; his name is Imozes.

Now let me settle myself to a long night's sleep, to which end my attendants take charge of my birds, prepare my lodging, and signify to me by signs how I must order myself. It was then about the middle of September, when I perceived the aire more clear than ordinary, and, with the increase of the light, I began to feel myself first dull, and then heavy to sleep, though I had not been lately disturbed of my rest. At length I delivered myself into the custody of this sister of death, whose prisoner I was for almost a fortnight after, and then awaking, it is not to be believed how brisk and vigorous I found the faculties both of my body and mind. I then applied myself to learning the language, which is the same throughout all the regions of the moon, yet not so wonderful, since I believe all the earth of moon does not amount to the fourtieth part our inhabited earth; partly besides the globe of the moon is far less, and because the sea or ocean covers very nigh three parts of four, whereas the land and sea in our world may be judged of an equal measure. Their language is very difficult, since it hath no affinity with any other I ever heard, and consists not so much of words and letters, as tunes and strange sounds, which no letterscan express; for there are few words but signify several things, and are distinguished only by their sounds, which are sung, as it were, in uttering. Yea, many words consist of tunesonly without words; by occasion whereof, I find a language may be formed, and easily learned, as copious as any other in the world. only of tunes, which is an experiment worth searching after. Notwithstanding these difficulties, within two months I attained to such knowledge therein, that I understood most questions demanded of me and, with signs and words, made reasonable shift to utter my mind: which Pylonas having notice of, he oftentimes sent for me, and was pleased to inform me of many things my guardians durst not disclose; though I must needs say, I never found they abused me with an untruth, but, if I asked a question they were unwilling to resolve, they would shake their heads, and with a Spanish shrug, divert to some other discourse

After seven months time, the great Irdonozur, making his progress to a place about two-hunderd leagues from the Palace of Pylonas, sent for me; yet would not admit me into his presence, but discoursed me through a window, where $I$ might hear him, and he hear and see me at pleasure. I presented him with the remainder of my jewels, which he thankfully accepted, saying, he wonld requite them with gifts of more considerable value. I staid there above a quarter of a moon, when I was again sent back to Pylonas, for if we had staid a day or two longer, the sun would have overtaken us, before we could have recovered our home. The gifts he bestowed on me were such, that a man would part with mountains of gold to purchase; they were all stones nine only in number, of three sorts, one called Poleastis, another Machrus, and the third Ebelus, 
of each sort three; the first are about the bigness of an hasle-nut, very like jet, which among many other incredible virtues hath this property, that being once put in the fire, they ever after retain their heat, though without any outward appearance, till quenched with some kind of liquor, which no way damages them, though heated and cooled therein a thousand times; their heat is so vehement, that it will make any metal, within a foot of it, red-hot, and being in a chimney, warms the room as if a great fire were kindled therein. The Machrus is yet more precious, in colour like a topaz, so clear and resplendent, as though not above the bigness of a bean, yet being placed in the night, in the midst of a large church, it makes all as light, as if an hundred lamps were hanged round. Can any man wish for more useful properties in a stone than these? Yet my Ebelus is so excellent, that it may be much preferred before them, yea, prized above all the diamonds, sapphires, rubies, and emeralds, that our world can afford. The lunar colour is so exceeding beautiful, that a man would travel a thousand leagues to behold it; the shape is somewhat Hlat, of the breadth of a piece of eight, and twice the thickness; one side is of a more orient colour than the other, which, being clapped to a man's bare skin, takes away all the weight and ponderousness of his body, but turning the other side, it adds force to the attractive beams of the earth, either in this world or that, and makes the body half as heavy again. Do you not wonder now why I should so overprize this stone? Before you see me on earth again, youl will find $I$ have reason to value this invaluable jewel. I inquired whether they had not any kind of gem or other means, to make a man invisible, which I judged a thing of admirable use, and could mention divers of our learned men, who had written to this purpose; they answered, that if it were possible, yet they were sure, heaven would not suffer it to be revealed to us creatures, subject to so many imperfections, and which might be easily abused to ill purposes, and this was all I could get of them.

Now after it was known that Irdonozur the great monarch had done me this honour, it is strange how much all respected me, more than before. My guardians, who had been hitherto cautions in relating any thing of the government of that world, grew now more open, so that from them, and Pylonas together, I understood many notable particulars; as that, in a thousand years, there is found neither thief, nor whoremonger, for first there is no want of any thing necessary for the use of man, food growing everywhere without labour, of all sorts that can be desired. As for clothes, houses, or whatever else a man may be supposed to want, it is provided by their superiors, though not without some labour, but yet so easy, as if they did it for pleasure. Again their females are all absolute beauties, and by a secret disposition of nature, a man there laving once known a woman wever desires any other. Murder was never heard of amongst them, neither is it hardly possible to be committed, for there can be no wound made but what is curable; yea, they assured me, and for my part I believe it, that though a man's head be cut off, yet if within three moons if be joined to the carcass again, and the juice, of a certain herb there growing applied, it will be so consolidated as the 
wounded party shall be perfectly cured. But the chief cause of their good government is an excellet disposition in the nature of the people, so that all, both old and young, hate all manners of vice, and live in such love, peace and amity, as it seems to be another paradise; though it is true likewise, that some are of a better disposition than others, which they discern immediately at their birth. And because it is an inviolable law amongst them, that none shall be put to death, therefore, perceiving by their stature, or some other signs, who we like to be of a wicked and debauched humour, they send them, I know not by what means, into the earth, and change them for other children, before they lave either opportunity or ability to do amiss among them; but first, they say, they are fain to keep them there for some time, till the air of the earth alters their colour like ours. Their ordinary vent for them is a certain high hill, in the north of America, whose people, I am apt to believe, are wholly descended from them, both in regard of their colour, and their continual use of tobacco, which the Lunars, or Moon-men smoke, exceedingly, the place abounding much with moisture, together with the pleasure thes take therein, and some other respects, too long to rehearse. Sometimes, though but seldom, they mistake their aim, and fall upon Europe, Asia or Africa. I remember some years since, I read certain stories tending to confirm what is related by these Iunars, and especially one chapter of Neubrigensis. Inigo Montejar, in his description of Nova Granada; also Joseph Defia de Carana, in his history of Mexico, if my memory fail not, recount what will make my report more credible; but I value no testimonies.

If you inquire how justice is executed, alas! what need is there of exemplary punishment, where no offences are committed? Neither need they any lawyers, for there is no contention, the seeds whereof, when they begin to sprout, are by the wisdom of the next superior plucked up by the roots. And as little want is there of physicians, they never surfeit themselves; the air is likewise pure and temperate, neither is there any cause of sickness; I could never hear of any that were distempered. But, the time assigned them by nature being spent, they die without the least pain, or rather cease to live, as a candle does to give light, when what nourishes it is consumed. I was once at the departure of once of them, and was much surprised that notwithstanding the happy life he lived, and the multitudes of friends and children he should forsake, yet as soon as he understood his end to approach, he prepared a great feast, and, inviting all whom he esteemed, exhorts them, 'To be merry, and rejoice with him, since the time was come he should now leave the counterfeit pleasures of that world, and be made partaker of all true joy and perfect happiness'. I did not so much admired his own constancy, as the behaviour of his friends; with us in the like case all seem to mourn, when many of them do often but laugh in their sleeves, or under a 
vizard. But here all, both young and old, did, on my conscience, not pretendedly but really rejoice thereat, and if any dissembled, it was only grief for their own particular loss. Being dead, their bodies putrefy not, and so are not buried, but kept in certain rooms appointed to that purpose, so that most of them can shew their ancestor bodies uncorrupt for many generations. There is never any rain, wind, or change of weather, never either summer or winter, but as it were a perpetual spring, yielding all pleasure and content, free from the least trouble or annoyance. $0 \mathrm{my}$ wife and children, what wrong have you done me to bereave me of the happiness of that place! But it is no great matter, for by this voyage, I am sufficiently assured, that, when the race of my mortal life is run, I shall attain a greater happiness elsewhere.

It was on the $9^{\text {th }}$ of September, that $I$ began to ascend the Pike of Teneriffe; twelve days I was upon my voyage, and arrived in that province of the moon called Semiri, September the $21^{\text {st. May }}$ the $12^{\text {th }}$, we came to the court of the great Irdonozur, and returned back the $17^{\text {th }}$ to the palace of Pylonas, where I continued till March, 1601, when I earnestly requested Pylonas, as I had often done before, to give me leave to depart, though with hazard of my life, back into the earth again. He dissuaded me, insisting on the danger of the voyage, the misery of that place from whence I came, and the abundant happiness I now enjoyed, but the remembrance of my wife and children outweighed all these reasons; and, to say the truth, I was so elated with a desire of the glory I should purchase at my return, as, methought, I deserved not the name of a Spaniard, if I would not hazard twenty lives, rather than lose the least particle thereof. I replied, I had so strong a desire to see my children, that I could not possibly live any longer without going to them. He then requested me to stay one year longer; I told him I must needs depart now or never; my birds began to droop for want of their usual voyage, three werc already dead, and, if a few more failed, I was destitude of all possibility of return. At length, with much solliciting, I prevailed, having first acquainted the great Irdonozur, with my intentions, and perceiving, by the often baying of my birds, a great longing in them to be gone, I trimmed up my engine, and took my leave of Pylonas; and March the 29th, three days after my waking from the last moon's light, I fastened myself to my engine, not forgetting to take the jewels Irdonozur had given me, with the virtues and use whereof Pylonas had acquainted me at large, with a small quantity of victuals, whereof, afterwards, I had great, occasion. A vast multitude of people being present, and amongst them, Pylonas himself, after 1 had given them all the last farewel, I let loose the reins to my birds, who, with much greediness, taking wing, quickly carried me out of sight. It happened to me as in my first passage, for I never felt either hunger or thirst, till I fell upon an high mountain in China, about five leagues from the high and mighty city of Pequin. 'This voyage was performed in less than nine days, neither heard $I$ any news of these airy men I met with in my ascending; nothing staid me in my journey; whether, because of the earnest desire of my birds to return to the earth, having already missed 
their season, or that the attraction of the earth was much stronger than that of the moon, and so made it easier, yet so it was, though I had three birds less than before. For the first eight days my birds flew before me, and $I$ on the engine was, as it were, drawn after; but the ninth day, when I began to approach the cloud, I perceived myself and engine to sink towards the earth, and go before them. I was then horribly afraid lest my birds, unable to bear our weight, being so few, should be constrained to precipitate both me and themselves headlong to the earth, and thought it very necessary to make use of my stone Ebelus, which I clapped to my bare skin within my clothes, and instantly I perceived my birds made way with greater ease than before, as seeming freed from a great burden, neither do I think they could possibly have let me down safely to the earth without that help.

China is a country so populous, that $I$ think there is scarce a piece of ground thrice a man's length which is not carefully manured. I being yet in the air, some of the country people, espying me, came running by troops, and seizing me, would needs carry me before a magistrate, and, sceing no other remedy, I yielded to them. But, when I tried to go, I found myself so light, that one foot being on the ground, I had much ado to set down the other, which was, by reason my Ebelus took all weight away from my body; therefore I pretended a desire of performing the necessities of nature; which being made known to them by signs, for they understood not a word of any language I could speak, they permitted me to go aside amongst a few bushes, assuring themselves it was impossible I should escape from then. Being there, I remembered Pylonas's directions about the use of my stones, and knit them up, with a few remaining jewels, into an bandkerchief, all, except the least and worst Ebelus, which I found means to apply in such a manner to my body, that but the half of its side touched my skin. This done, I drew towards my gardians, till coming so near, that, they could not cross my may, I shewed them a fair pair of heels, that I might have time to hide my jewels, which I know they would have robbed me of, if not prevented. Being thus lightened, I led them such a dance, that, had they been all upon the backs of so many race-horses, they could never have overtaken me. I directed my course to a thick wood, wherein I entered about a quarter of a league, and there finding a fine spring, which I took for my mark, I thrust my jewels into a mole hard by.

I then took my victuals ont of my pocket, to which, till now, in all my voyage, I had not the least appetite, and refreshed myself therewith, till the people, who pursued, overtook me, into whose hands I quietly surrendered myself. They led me to an inferior officer, who understanding that I escaped from those who first apprehended me, caused an inclosure of boards to be made, wherein they put me; so that only my head was a liberty, and then carried me upon the shoulders of four slaves, like some notorious malefactor, before a person of great authority, who, in their language, I learned was called a Mandarin, and resided a league off the famous city of Pequink. I could not understand them, but found I was accused for something with much vehcmence; the substance of this 
accusation, it seems, was, that I was a magician, as appeared by my being so strangely carried in the air, and that, being a stranger, as both my language and habit did declare, I, contrary to the laws of China, had entered the kingdom withont a warrant, and probably for no good intent. 'The mandarin heard them with a great deal of gravity, and being a man of quick apprehension, and studious of novelties, he told them he would take such order as the case required, and my bold attempt should not go unpunished. Having dismissed them, he ordered his servants I should be kept in a remote part of his vaste palace, be strictly guarded and kindly used. This I conjecture by my treatment, and what followed; for my accomodation was much better than I could expect. I lodged well, eat well, was well attended, and could complain of nothing but my restraint. Thus continued I many months, afflicted more with the thoughts of my gansa's than any thing else, who I knew must be irrevocably lost, as indeed they were.

In this time by my own industry, and the assistance of those who accompanied me, I learned to speak indifferently the language of that province (for almost every province in ('hina bath its proper tongue), whereat I perceived they were much pleased. As length I was permitted to take the air, and brought into the spacious garden of that palace, a place of extraordinary pleasure and delight, adorned with herbs and flowers of admirable sweetness and beauty, with almost infinite variety of fruits, European, and others, all composed with that rare curiosity, as even ravished my senses in the contemplation of such delightful objects. I had not long recreated myself here, when the mandarin entered the garden on that side I was walking, of which, having notice by his servants, and that 1 ought to kneel to him (a usual reverence I found towards great officers) I did so, and humbly intreated his favour towards a poor stranger who arrived in these parts, not designedly, but by the secret disposal of the heavens. Ile answered in a different language, which $I$ hearall the mandarins use, and like that of the Lunars, consisting chiefly of tunes, which was interpreted by one of his attendants, wishing me to be of good comfort, since he intended no harm to me. Next day I was ordered to come before him, and, being conducted into a noble diningroom exquisitely painted, the mandarin, commanding all to avoid, vouchsafed to confer with me in the vulgar language; inquiring into the state of my country, the power of my prince, and the religion and manners of the people; wherein having satisfied him, he asked about my education, andwhat brought me into this remote country. I then declared to him the aventures of my life, omitting what I thought convenient, and especially forbearing to mention the stones given me by Irdonozur.

The strangeness of my story did much amaze him, and finding in all my discourse, nothing tending to magick, wherein he hoped, by my means to be instructed, he began to admire the excellency of my wit, applauding me for the happiest man that this world ever saw; and, wishing we to repose myself after my long narration, he, for that time, dis- 
missed me. After which the mandarin took so much delight in me, that no day passed wherein he did not send for me. At length he advised me to clothe myself in the habit of that country, which I willingly did, and gave me not only the liberty of his house, but took me also with him when he went to Pequin, whereby I had opportunity to learn the disposition of the people, and the policy of the country. Neither did I, by my attendance on him, gain only the knowledge of these things, but the possibility likewise of being restored to my native soil, and to those pledges which I value above the world, even my wife and children; for, by often frequenting Pequin, $I$ at length heard of some fathers of the society of Jesus, who were become famous for their extraordinary favour with the king, to whom they had presented some European gifts, as clocks, watches, dials, and the like, which, by them, were counted exquisite curiosities. To these, by the mandarin's leave, I repaired, and was welcomed by them, they much wondering to see a lay Spaniard there, wither they had, with so much difficulty, obtained leave to arrive. There did I relate to Father Pantoja, and others of the society, the forementioned adventures, by whose directions I put them in writing, and sent this story of my fortunes to Macao, from thence to be conveyed to Spain as a forerunner of my return. And, the mandarin being indulgent to me, I came often to the fathers, with whom I consulted about many secrets, and with them also, laid the foundation of my return, the blessed hour whereof I do, with patience, expect; that, by inriching my country with the knowledge of these hidden misteries, I may at last reap the glory of my fortunate misfortunes.

\section{Bemerkungen zu Godwin's 'Voyage of Domingo Gonzales to the Moon'.}

Vorstehender traktat des gelehrten bischofs zu Llandaff, Dr. Francis God win (1561-1633 nach Allibone, 'A critical dictionary of English Literature', vol. I, p. 682), entstand nach Antony Wood (Athenae Oxonienses, vol. II, col. 558) während der studienzeit des verfassers zu Oxford. Nach inneren beweisen, wie Henry Hallam in seiner 'Introduction to the literature of Europe in the $15^{\text {th }}, 16^{\text {th }}$ and $17^{\text {th }}$ centuries, vol. III, p. 684 sagt, ist dieser fabelhafte reiseroman nach 1599 und vor dem tode der Elisabeth 1603 entstanden. Veröffentlicht erschien derselbe zuerst zu Perth 1638, worauf nach Allibone, mehrere ansgaben gefolgt sind. Nach Hallam, a. a. o., wurde er in das Französische thbersetzt und wurde dadurch ein vor- 